\title{
APPLICATION OF FULL FAITH AND CREDIT CLAUSE TO EQUITABLE DECREES FOR THE CONVEY- ANCE OF FOREIGN LAND*
}

\author{
ERNEST G. LORENZEN.
}

The Constitution of the United States provides: "Full faith and credit ishall be given in such state to the public acts, records and judicial proceedings of every other state. And the Congress may by general laws prescribe the manner in which such acts, records and proceedings shall be approved, and the effect thereof."

In pursuance of the power vested in it, Congress has prescribed the mode of authentication and the effects of such acts, records and proceedings as follows:" "and the said records and judicial proceedings so authenticated shall have such faith and credit given to them in- every court within the United States as they have by law or usage in the courts of the state from which they are taken."

It is a settled rule that the full faith and credit clause applies only to substantive rights and that it has no application to matters of procedure. $^{2}$ Hence, if it can be shown that equitable decrees do not establish obligations, that is, right-duty relations, but are merely methods for the enforcement of existing legal relations, it follows of course that they are not within the purview of the full-faith and credit clause.

The first issue relates therefore to the nature and effect of equitable decrees in general.

If we go back as far as the Year Books we find Knightly, Sergeant at Law, making the following statement: ${ }^{3}$

"A decree is not like a judgment in the King's Bench or Common Bench, for such a judgment binds the right of the party; but a decree does not bind the right, but only the person to obedience, so that if the party will not obey, then the Chancellor may commit him to prison until he will obey and this is all that the Chancellor can do."

In another Year Book case the following appears: 4

* The writer wishes at the outset to acknowledge his deep obligations to Professor W. W. Cook and to the late Professor Willard Barbour. The fundamental views presented in this paper, founded on an address by the present writer before the Round Table on Public Law of the Association of American Law Schools at their meeting in Chicago in December, 1924, were first worked out in an article entitled "The Powers of Courts of Equity" (I9I5) I5 CoL. L. REv. 37, 106, 228, by Professor Cook, and further developed in an article entitled "The Extra-Territorial Effect of the Equitable Decree" (1919) I7 MICH. L. Rev. 527, by Professor Barbour.

${ }^{1}$ Act of May 26, I790, U. S. Rev. Sts. I790, sec. 905.

${ }^{3}$ McElmoyle v. Cohen (1839, U. S.) I3 Pet. 312.

${ }^{3}$ Y. B. 27 Hen. VIII, f. 15, p1. 6.

'Y. B. 37 Hen. VI, f. 13, pl. 3; Jenk. Cent. Cas. 108, pl. 9; I Ames, Cases on Equity (IgOI) 2, note I. 
"For the common law proceeds upon fixed and invariable rules; the Chancery proceeds upon the discretion of a good man. A decree there binds the person to obedience, but it does not operate at all upon the matter in question."

Referring to the above cases, Coke expressed the matter as follows: 5

"This court of equity, proceeding by English bill is no court of record and therefore it can bind but the person only, and neither the estate of the defendant's lands nor the property of his goods and chattels."

From the following extracts from eminent American writers it would seem as if there still existed a fundamental difference between judg-

- ments at law and decrees in equity. One of these writers said in $1883:{ }^{6}$

"Indeed, it may be stated broadly that a decree in chancery has not in itself (i. e., independently of what may be done under it) any legal operation whatever. If a debt, whether by simple contract or by specialty, be sued for in a court of law, and judgment recovered, the original debt is merged in the judgment, and extinguished by it, and the judgment creates a new debt of a higher nature, and of which the judgment itself is conclusive evidence. But if the same debt be sued for in the court of chancery (as it frequently may be) and a decree obtained for its payment, not one of the effects before stated is produced by the decree. Undoubtedly it has often been said by chancellors that their decrees are equal to judgments at law, but that only means that they will, to the extent of their power, secure for their decrees the same advantages that judgments have by law; it does not mean that a decree is by law equal to a judgment.

"Again, if a claim be made the subject of an action at law, and judgment be rendered for the defendant upon the merits, the judgment is conclusive evidence that the claim was not well founded, and it will therefore furnish a perfect defense to any future action upon the same claim; but a decree in equity against the validity of a claim is never a defense to an action at law upon the same claim. Here again, however, the chancellor will make his decrees equal to judgments so far as it is in his power to do so; and therefore a decree in chancery against a claim upon its merits will always be a defense to any future suit in chancery upon the same claim, not as destroying the claim or as proving conclusively its invalidity, but as furnishing a sufficient reason why chancery should not again take cognizance of it. Such a decree will also be (what is sometimes called) an equitable defense to any action at law upon the same claim, i. e., the chancellor will enjoin the prosecution of any such action, upon the ground that the plaintiff having elected to make his claim the subject of a 'suit in equity, and that suit having been defended successfully upon the merits, it is not right that the defendant should be vexed again by the same claim."

Another writer expressed himself in 1902 as follows:?

"An equitable decree for the doing of an act, except the mere payment of money, is not by our law enforceable in another court, even of the same state; there is no form of proceeding for enforcing the merely personal decree of a court of equity, except by order of the court rendering

${ }_{4} 4$ Coke, Institutes,* 84.

- Langdell, Summary of Equity Pleading (2d ed. 1883) 37, sec. 43, n. 4.

" 3 Beale, "Summary of the Conflict of Laws," Cases on the Conflict of Laws (xg0z) 536, 537. 
it. It is, therefore, impossible to enforce a foreign decree that an act be done by the defendant, such as making a conveyance, either by decreeing the conveyance without judicial investigation or by regarding it as made. An additional objection to enforcing such a decree is that it is not in its nature the establishment of an obligation, but rather a method of enforcing an obligation, a form of execution."

Still another writer used the following language in $1920:^{8}$

"But it is to be noted that it is only money judgments that are enforced abroad, and that this "enforcement of the judgment" is a dogmatic fiction. In the Roman law the claim sued on underwent a novation in the 'procedural contract' of litis contestatio. In our law the debt used on was merged in the judgment. Hence in legal theory the original claim no longer existed, and in order to allow it to be asserted abroad, it became necessary to invoke a 'quasi-contractural' obligation to pay the judgment. But in equity the suit is to compel defendant to do his duty and that duty is not necessarily merged in the decree, so that if the decree fails of effect, an action may still be brought upon plaintiff's legal right, if he has one. Thus, there was never any necessity for proceeding subsequently on a theory of enforcing the decree rather than the original claim."

Other writers have challenged in recent years the correctness of the statements contained in the above extracts. In I9rg one of these critics said $^{9}$ that statements like the above assume "that equity has made no progress since the time of Coke." In another place he said, "The notion that an equitable decree which orders the conveyance of land cannot create a binding obligation is the last survival of an old dogma which is to-day shorn of most of its force."

Another critic writing four years earlier and voicing the same sentiment, asked the question: "I1 "Is it not time for judges and writers to stop talking language suitable to the time of Coke in discussing the power of equity, and'to recognize that a court of equity is a legal tribunal with powers to adjudicate and settle controversies as finally as a court of law ?"

This is not the proper time for a detailed examination of the history of equity since the time of Lord Coke for the purpose of ascertaining how the nature of equitable decrees has changed since those days when the court of chancery was merely a court of conscience. Let us examine the question simply from the standpoint of our own law of to-day. Let us consider, first, whether there is any important difference to-day between judgments at law and equitable decrees as regards the doctrine of res judicata and merger..

Suppose $A$ claims that $B$ owes him $\$$ Ioo and that after a hearing on the merits, a judgment is rendered in B's favor. If $A$ should sue $B$

'Pound, The Progress of the Law-Equity (I920) 33 HARv. L. Rev. 420, 424.

- Barbour, op. cit. sitpra * note, 528 .

${ }^{10}$ Ibid. 539.

${ }^{11}$ Cook, op. cit. supra * note, 233-234. 
again for the $\$$ Ioo, $\mathrm{B}$ can defeat A's claim by the plea of res judicata. If the judgment in the first suit were rendered in A's favor, it would operate as a merger of the cause of action and a second suit could not be brought on the original cause of action. Would the same results obtain if the suits had been in equity? Let us see how our courts answer this question.

In Young v. Farzell, ${ }^{12}$ the plaintiff sued the defendant for the reasonable value of services. The defendant answered that an action had been brought against him 'by the plaintiff in a chancery court of Illinois on the same cause of action and that a final decree had been rendered between the parties in favor of the defendant and against the plaintiff. It was held 'that the judgment of the Illinois court was a conclusive adjudication against the plaintiff's claim. The court said:13

"It makes no difference that the judgment, or decree, set up by way of estoppel, was one rendered in an equitable action for an accounting; provided that the question involved in this common law action was involved and determined in the equity action. That a decree rendered in a cause, depending between parties in equity, may be a bar to an action at law between them cannot be questioned."

In Harrington $v$. Harrington, ${ }^{14}$ assumpsit was brought on a contract for rents and profits. The same matter which was!in dispute in this suit was included in a suit in equity in Rhode Island and had been heard and passed upon there and a final decree entered in favor of the plaintiff. It was held that the equitable decree was a bar to the action. The court said : ${ }^{15}$

"Whether, therefore, the court in that state was 'a court of law or equity, of admiralty or probate,' the matter in controversy and the parties being the same in this suit as in that, the judgment of that court is conclusive and is a bar to the present action."

In another case, Mutual Life Ins. Co. v. Newton, ${ }^{16}$ the plaintiff foreclosed a mortgage in New Jersey and got a statutory decree for deficiency. He later sued on the bond secured by the mortgage. It was held that plaintiff's rights arising from the execution of the bond had been extinguished. The court said : ${ }^{17}$

"The doctrine of res adjudicata is plain and intelligible, and amounts simply to this: that a cause of action once finally determined without appeal between the parties, on the merits, by a competent tribunal, cannot afterwards be litigated by a new proceeding, either by the same or any other tribunal.... And this is true, whether the first adjudication is in a court of law or equity.... Hence, it is settled that a verdict and judgment of a court of record or a decree in chancery, puts an end

${ }^{22}$ (I90I) r65 N. Y. 34r, 59 N. E. 143.

${ }^{13}$ At p. 345,59 N. E. 144 .

${ }^{14}$ (I89I) I54 Mass. 517,28 N. E. 903.

${ }^{15}$ At p. 5I9, 28 N. E. 903.

${ }^{10}$ (1888) 50 N. J. L. 57r, 14 Atl. 756.

${ }^{17}$ At p. 576-577, I4 Atl. 759. 
to all further controversy concerning the points thus decided between the parties to the suit. ... If the decree is final, then its result is to merge the original cause of action.

In view of these and other cases ${ }^{18}$ holding the same doctrine, it is apparent that the statement made by the third writer, quoted from above-"but in equity the suit is to compel defendant to do his duty and this duty is not necessarily merged in the decree so that if the decree fails of effect, an action may still be brought upon plaintiff's legal right, if he has one"10_does not apply to causes of action involving the payment of money. ${ }^{20}$

It must be likewise apparent that the statement made in 1883 by the writer quoted from above - "if a debt . . . be sued for in a court of law and judgment recovered, the original debt is merged in the judgment, and extinguished by it, and the judgment creates a new debt of a higher nature, and of which the judgment itself is conclusive evidence. But if the same debt be sued for in the court of chancery (as it frequently may be) and a decree obtained for its payment, not one of the effects before stated is produced by the decree"21-does not express accurately the existing law.

Let us now examine the other assertion made by the same writer, namely, that the judgment at law creates a new debt of a higher nature and of which the judgment itself is the conclusive evidence, whereas the decree for the payment of money has no such effect. Otherwise expressed, the argument is that a judgment at law' creates a new obligation; a decree in equity for the payment of money does not. This is a most important point in the discussion of this topic, for if an equitable decree for the payment of money does not create a new obligation, a new right-duty relation, it will, in the nature of things, be difficult, if not impossible, to establish such with reference to equitable decrees for the doing of some other act, for example, the conveyance of land.

What do the courts hold on this point? As early as I794 there was a Connecticut case, ${ }^{22}$ in which an action of debt was brought for 60 pounds, declaring upon a degree in chancery for the penalty of 60 pounds. The jury having found for the plaintiff, the defendant moved in arrest of judgment that the declaration of the plaintiff was insufficient,

\footnotetext{
${ }^{23}$ See for example Dobson v. Pearce (1854) I2 N. Y. 156, where it was held that a Connecticut decree determines conclusively that a New York judgment had been obtained by fraud. In regard to this case, see Cook, op. cit. supra * note, 248-249. In Fromholz v. McGahcy (I9I5) I20 Ark. 216, a Nebraska decree dismissing a bill to set aside a deed to Nebraska land was held conclusive.

Io Pound, loc. cit. supra note 8.

${ }^{\circ}$ Nor would it seem to apply to decrees for the doing of something other than the payment of money. Fitzgerald $v$. Heady (I9I6) 225 Mass. 75, Ir3 N. E. 844

${ }^{27}$ Langdell, op. cit. supra note 6,37 .

"Drakesly v. Roots (1794) 2 Root, 138; given also in I Cook, Cases on Equity (rg24) gr.
} 
for an action of debt at law would not lie for a penalty incurred upon a decree in chancery. The opinion reads $:^{23}$

"The court were clearly of opinion that the action well lay, for an action of debt lies for a sum certain, either by simple contract, by specialty, by judgment of court, by statute, or by decree in chancery, if the thing decreed be performed under a penalty is not performed, the penalty is incurred and becomes a debt."

In Post v. Neafie, ${ }^{24}$ an action of debt was brought upon a decree pronounced by the court of chancery for the state of New Jersey. At the trial the defendant moved for a non-suit on the ground inter alia that no action at common law would lie to enforce the decree of a court of chancery, domestic or foreign. It was held that the action would lie and that decision has been followed practically ever since. ${ }^{25}$

The Supreme Court of the United States has held that equitable decrees for the payment of money, provided they are final, must be given the same effect as judgments at law under the full-faith and credit clause of the Federal Constitution. ${ }^{26}$

Notwithstanding this array of authority, those subscribing to the orthodox view contend that the new obligation created by the equitable decree arises not!from principles of equity but from the operation of legislation which has placed equitable decrees for the payyment of money upon the same footing as judgments at law. Effect is given, it is said, to the foreign equitable decree because in the jurisdiction in which it was rendered it had been given the same effect as a judgment at law. This contention is made, although no such limitation appears from the cases. In the leading case above referred to, Post $v$. Neafie, there was such a statute in New Jersey, but Livingston, J., stated expressly ${ }^{27}$

"I lay no stress on the statute of New Jersey, which renders a decree in chancery of equal effect with a judgment of its supreme court; because, for the purpose of this action, we are not bound to take notice of the manner of proceeding in a foreign court of equity, even admitting, which we do not know judicially, that they are the same as with us; it is enough that it has settled what is due from the one to the other of the parties litigant. But if I had the smallest doubt of the propriety of this suit, this statute would remove it."

As statutes of the type referred to have existed from very early times, it may very well be that in the cases adopting the rule laid down in Post v. Neafie, there actually were such statutes in the states in which the

\footnotetext{
${ }^{23}$ Loc. cit.

${ }^{24} 3$ Caines (I805, N. Y.) 22.

${ }^{25}$ An action of debt or a similar action has been held to lie also in the same state for the enforcement of a domestic decree for the payment of money. Ames v. Hoy (1859) I2 Calif. II, 20; Howard v. Howard (1818) I5 Mass. I96; see also Cook op. cit. supra* note, 242-243.

${ }^{26}$ Lynde v. Lynde (Ig0I) 181 U. S. 183, 21, Sup. Ct. 555 ; Sistare v. Sistare (IgIo) 2I8 U. S. I, 30 Sup. Ct. 682.

${ }^{n}$ Op. cit. supra, note 24 , at p. 33 .
} 
decrees were rendered. Even if it should appear that such were the case, it would seem, however, from the cases that the result was reached on principle and not because of the statutes.

But even if it were conceded for the sake of argument that an action at law for the enforcement of foreign decrees could not have been brought in this country at the time Post $v$. Neafie was decided in 1805 , in the absence of statutes giving equitable decrees for the payment of money the same effect as judgments at law, it would by no means follow that the decree did not create a new right-duty relation between the parties, an obligation, but imposed merely a personal duty to the court. For our purpose it is sufficient if it can be shown that an equitable decree for the payment of money created a right, legal or equitable. The question is thus whether at the time of the decision of Post v. Neafie a decree of equity created, if not a legal, at least an equitable right. We have the opinion of no less an authority than that of Chancellor Kent to the effect that a decree did create an equitable right. He felt that there was no authority for allowing an action at law upon a foreign equitable decree, statute or no statute, and was unwilling to take such a forward step in the absence of precedent. He dissented, therefore, in that case from the majority of the court. Relying upon a case decided by Lord Hardwicke in I737, he held, however, that the plaintiff had an equitable right and that instead of suing at law, he should have proceeded to enforce such right in equity. He says :28

"The plaintiffs are not without remedy in the present case, since our court of chancery is the proper tribunal for them to resort to; and for this we have an authority in Morgan's case, in the time of Lord Hardwicke, I Atk. 408. In that case a Welsh court of equity had decreed payment of a legacy, and the defendant, to avoid execution of that decree, fled into England. A bill was filed before Lord Hardwicke, stating the proceedings and decree in Wales, and the flight of the defendant, and the chancellor sustained the bill after demurrer, holding that an original independent decree might be had in that court for the legacy."

We have herein a clear recognition of the fact that a decree in equity for the payment of money imposes not merely a personal duty on the defendant with reference to the particular court, but that it creates an equitable right which can be enforced elsewhere. The criticism that has been made of cases like Mallette v. Scheerer, ${ }^{29}$ and Matson v. Matson, ${ }^{30}$ that they rest upon the false analogy of the enforcement of foreign judgments and of foreign money decrees, ${ }^{31}$ is, therefore, without foundation.

The above development in our law has met with great opposition, for

${ }^{23}$ Ibid. at p. 36.

20 (1916) 164 Wis. 415,160 N. W. 182.

(1919) I86 Iowa, 607, 173 N. W. I27.

"1 Pound, op. cit. supra note $8,424$. 
the notion that judgments at law are fundamentally different from equitable decrees has been accepted by Anglo-American lawyers since the days of Lord Coke as such an elementary and self-evident proposition that only the most pressing arguments of convenience have been able to induce the courts to abandon the old dogma. Although courts of equity have long since become courts of record and are coördinate with courts of law in our modern legal system, presided over often by the same judges, there has been a tendency to repeat the traditional phrases about the relation of law and equity, judgments at law and decrees in equity. We find, therefore, that every step taken in the direction of placing decrees of equity on the same footing with judgments at law has been taken only after a severe struggle. As has been shown above, decrees for the payment of money are at length recognized as res judicata, as merging the original cause of action and as creating an equitable right which may be enforced in other jurisdictions by a new suit. This much is admitted, although, as we have seen, it is still sought to ascribe the development of the doctrine that equitable decrees for the payment of money are enforceable in other jurisdictions to the operation of statutes rather than to a change of attitude on the part of the courts with reference to equitable decrees themselves.

In the light of this, it will not be surprising to find even stronger apposition to the idea that equitable decrees ordering something other than the payment of money-for example, the conveyance of foreign land-should of themselves have any effect other than imposing a personal duty on the defendant with respect to the particular court. Before considering the grounds upon which the specific objections to this new step in the development of our law are based, let us see what the American cases actually hold on the subject.

As early as 1873 , we find a decision which has been a great stumbling block to the adherents of the orthodox view. This is the case of Burnley v. Stevenson. ${ }^{32}$ In that case A, who had agreed to convey to $B$ certain land in Ohio, died without making the conveyance and $B$ thereupon brought in Kentucky in a court of equity suit against A's heirs. The court entered a decree ordering the heirs, who were before the court, to convey the land to $B$ and in default thereof directing a master of the court to make the conveyance. Defendant, who succeeded to B's rights, 'obtained possession of the land. Plaintiff sued in the right of A's heirs in Ohio to recover possession of the land. Defendant in his answer set up the Kentucky decree and the master's deed. This answer was held to constitute a good equitable defense. The court said:

"That courts exercising chancery powers in one state have jurisdiction to enforce a trust, and to compel the specific performance of a contract in relation to lands situate in another state, after having

82 (1873) 24 Ohio St. $474,478$. 
obtained jurisdiction of the persons of those upon whom the obligation rests, is a doctrine fully settled by numerous decisions.

"It does not follow, however, that a court having power to compel the parties before it to convey lands situated in another state, may make its own decree to operate as such conveyance. Indeed, it is well settled that the decree of such court can not operate to transfer title to lands situate in a foreign jurisdiction. And this, for the reason that a judgment or decree in rem cannot operate beyond the limits of the jurisdiction or state wherein it is rendered. And if a decree in such case cannot effect the transfer of the title to such lands, it is clear that a deed executed by a master, under the direction of the court, can have no greater effect....

"This decree was in personam, and bound the consciences of those against whom it was rendered. In it, the contract of their ancestor to make the conveyance was merged. The fact that the title which had descended to them was held by them in trust for Evans [B], was thus established by the decree of a court of competent jurisdiction. Such decree is record evidence of that fact, and also of the fact that it became and was their duty to convey the legal title to him. The performance of that duty might have been enforced against them in that court by attachment as for contempt, and the fact that the conveyance was not made in pursuance of the order does not affect the validity of the decree in so far as it determined the equitable rights of the parties in the land in controversy. In our judgment, the parties, and those holding under them with notice, are still bound thereby.

"Under our Code of Practice, equitable as well as legal defenses may be set up in an action for the recovery of land. The defendant in the court below set up this decree of the circuit court of Kentucky as a defense to the plaintiff's action. That it did not constitute a good defense at law may be admitted, but we think, in equity, it was a sufficient defense.

"The Constitution of the 'United States declares that full faith and credit shall be given in each state to the records and judicial proceedings of every other state, and provides that Congress may prescribe the mode of proving such records and proceedings, and the effect thereof. By an act of May 26, I79o, Congress declared that the 'records and judicial proceedings of the state courts,' when properly authenticated, 'shall have the same faith and credit given to them in every court within the United States as they have by law or usage, in the courts of the state. from whence they are or shall be taken.' When, therefore, a decree rendered by a court in a sister state, having jurisdiction of the parties and of the subject matter, is offered as evidence, or pleaded as the foundation of a right, in any action in the courts of this state, it is entitled to the same force and effect which it had in the state where it was pronounced. That this decree had the effect in Kentucky of determining the equities of the parties to the land in this state, we have already shown; hence the courts of this state must accord to it the same effect. True, the courts of this state cannot enforce the performance of that decree, by compelling the conveyance through its process of attachment; but when pleaded in our courts as a cause of action, or as a ground of defense, it must be regarded as conclusive of all the rights and equities which were adjudicated and settled therein, unless it be impeached for fraud."

In I880 the question came up before the Supreme Court of New York in the case of Roblin $v$. Long. ${ }^{33}$ In that case an action was brought in

\footnotetext{
${ }^{23}$ (1880) 60 How. Pr. 200.
} 
New York to enforce a decree of a court of chancery of Ontario, Canada, ordering the conveyance of land in Ontario. One of the defenses interposed was that the court had no jurisdiction to enforce such a decree. The court held the defense to be frivolous, saying: "This court having acquired jurisdiction of the person of the defendant, it possesses full power to enforce the judgment and decree of the chancery court of Canada, to the extent of compelling defendant to convey the lands mentioned in the complaint, though the same are situated in the province of Canada and without the jurisdiction of this court." In other words, the court here recognized that the Canadian decree ordering the defendant to convey to plaintiff Canadian land created a good equitable cause of action in New York.

The question came up before the Supreme Court of Michigan in I896 in the case of Dunlap v. Byers. ${ }^{34}$ Suit had been brought in Ohio for the dissolution of a partnership between $A$ and $B$. The court having jurisdiction of the parties decreed the dissolution of the partnership, appointed a receiver, and directed him to sell the interest of the partnership in certain lands in Michigan. The sale was made to $A$ and was duly confirmed by the court, the receiver being ordered to execute a bill of sale to A. B was ordered to execute a quit-claim to A but died before having obeyed the order of the court. B's heirs brought ejectment in Michigan against the purchasers of certain of those lands and executed a mortgage covering part of these lands to $C$, who was fully informed of the title to the property. A bill was thereupon filed to restrain B's heirs from prosecuting the action of ejectment and to compel them to transfer to complainants the legal title in accordance with the Ohio decree and to have the mortgage to $C$ declared void. A decree was entered in accordance with the prayer of the bill. B's heirs contended that the Ohio decree and sale thereunder was null and void for want of power in the court to make such a decree, and that the sale did not of itself divest or in any manner affect B's title to the lands in question. The court said:

"In effect, the rule is that, for the purposes of settlement, partnership lands cannot be distinguished from other assets. It therefore seems to us to appear conclusively that the superior court of Cincinnati acquired jurisdiction, not only over the parties, but over the subject matter, and had the power to adjudicate the rights of the parties in all the property belonging to the partnership, although a portion of the same was real estate in the state of Michigan. This appears to be the general rule, and is supported by a large number of authorities cited in the brief of counsel for the complainants. ....

"So the rule seems to be well settled that while the decree itself, in such cases, would not directly effect the transfer of title, the decree of the court would bind the consciences of the parties, and. could be enforced by a court within the territory where the property was located."

s4 (1896) I10 Mich. I09, 116, 67 N. W. I067, 1070. 
In I9r2, the following case came before the highest court of West Virginia in Roller $v$. Murray. ${ }^{35}$ Suit was brought for the specific performance of a contract to convey land in West Virginia. The contract also involved land in Virginia and suit for a specific performance had previously been brought in that state and the suit dismissed, the contract being declared champertous. This decree was set up in an answer to the suit for specific performance in West Virginia. Although the agreement to convey the land was valid by the law of West Virginia, it was held that the Virginia decree was entitled to full faith and credit. The court said:

"The validity of that contract was directly in issue in the Virginia court between the persons who are parties to this suit and the question of its validity actually decided ... that decision obviously and necessarily settles and determines that question in the state of Virginia and precludes any subsequent trial of it there between the same parties in any other litigation in which it may be material, no matter what the form of action or character or measure of relief sought. Being res adjudicata in Virginia, it must be so in West Virginia, because the Virginia decision must have the same faith and credit in all other states that it is entitled to in that state."

In I923, the following question came before the District Court of Appeal of California, in Redreod Investment Co. v. Exley. ${ }^{36}$ The defendant had entered into a contract with the plaintiff in Kentucky to convey to him his interest in California land. In a suit for specific performance in Kentucky, the defendant was ordered to make a conveyance of the land to the plaintiff. The defendant did not comply with the decree and before the time limited for the making of the conveyance, executed a deed of the land to $A$, who executed a mortgage to defendant. Defendant assigned the mortgage to $\mathrm{E}$. Plaintiff brought a bill in California, alleging the above facts, also that the several conveyances had been made without consideration and with full knowledge of the Kentucky decree. The plaintiff prayed that he be deemed the owner of defendant's interest in the land, that the deed to $A$ and the mortgage "by $A$ to $D$, together with the assignment thereof to $E$, be declared null and void and that $A$ be compelled to convey the land to plaintiff. The demurrer to plaintiff's petition was sustained by the trial court, but was reversed on appeal. The Supreme Court of the state denied a rehearing. The Court of Appeal said:

"There can be no question that real property is exclusively subject to the laws and jurisdiction of the state where located, and that no other laws or courts can affect it by an attempt to create, transfer, or vest title thereto. Judgments and decrees, therefore, which are rendered in one state cannot of themselves affect title to lands in another. From the very nature of the property land must be governed by the lex loci rei sitae.

× (1912) 71 W. Va. 161, 169, 76 S. E. I72, 176.

${ }^{36}$ (1923) 64 Calif. App. 455, 459, 22I Pac. 973, 975. 
"But this does not mean that a decree directing a conveyance is without its effect per se. It may be pleaded as a basis or cause of action or defense in the courts of the state where the land is situated and is entitled in such a court to the force and effect of record evidence of the equities therein determined, unless it be impeached for fraud."

The foregoing cases show that at least since the year 1873 decrees for the conveyance of land have been regarded by our courts as res judicata and that if pleaded as a basis or cause of action or defense in the courts of other states, they are entitled to the force and effect of record evidence of the equities therein. This is true also if the action is brought in the state where the land in question is situated.

I have omitted so far the cases of Bullock v. Bullock, ${ }^{37}$. decided by the court of Errors and Appeal of. New Jersey in I894; Fall v. Fall, ${ }^{38}$ decided by the Supreme Court of Nebraska in 1905, and affirmed in I'all v. Eastin, ${ }^{39}$ Mallette v. Scheerer, ${ }^{40}$ decided by the Supreme Court of Wisconsin, in I9I6; and Matson v. Matson, ${ }^{41}$ decided by the Supreme Court of Iowa in I9I9. These are divorce cases and I have grouped them apart in order that it might be apparent that the above doctrine has been fixed in our law without reference to statutes. If we leave out these divorce cases, it may be said that the cases without exception support the conclusion above stated.

The attempt has been made $\mathrm{e}^{42}$ to differentiate these two groups of cases on the theory that the courts enforced in the first group not the decree but the original cause of action, the foreign decree being merely regarded as conclusive evidence of the existence of the duty to convey. In this way it is sought again to square these decisions with the notion that equitable decrees do not create rights. In reply it must suffice to say that although the duty to convey arose in the first class of cases from contract, partnership or some other consensual relation, what was enforced was not the original cause of action but the decree. If the decree is conclusive evidence of the defendant's duty, the defendant is bound by it, whether right or wrong. The merits of the original cause of action cannot be inquired into. In other words, if fact $A$ (the original cause of action) is conclusively proved by fact $B$ (the judgment), the operative fact is $B$ and not $A$. The substantive rights of the parties must be clearly distinguished from mere matters of pleading.

${ }^{37}$ (I894) 52 N. J. Eq. 56r, 30 Atl. 676.

${ }^{83}$ (I907) $75 \mathrm{Neb}$. I04, II3 N. W. 175 .

30 (Ig09) 2 I5 U. S. I, 30 Sup. Ct. 3.

${ }^{40}$ Op. cit. supra note 29 .

¿ Op. cit. supra note 30 .

2 Notes (IgO8) 2I HARv. L. REv. 210. Nor is it possible to reconcile Mallette v. Scheerer and Matson v. Matson, on the one hand, with Bullock v. Bullock and Fall $v$. Fall, on the other, on the ground that there was an antecedent obligation in the former and none in the latter. In all of these cases the duty imposed on the defendant existed under the local law of the forum and no reference was had to the law of the situs. 
There is no escape from the conclusion, therefore, that in the above cases equitable duties to convey land created by the decree were rcognized and enforced by the courts of other states, including those of the state in which the land was situated.

Let us turn our attention now to the second group of cases where the duty to act with reference to foreign land did not arise out of contract, partnership or some other consensual relation, but was imposed in connection with a decree for divorce. As Mallette v. Scheerer and Matson v. Matson ${ }^{43}$ adopted the principle laid down in Burnley v. Stevenson and Dunlap v. Byers, which was followed also in the case of Redwood Investment Co. v. Exley, which cases have been discussed above, I shall not take the time to state them here. They are in accord with the view that decrees for the transfer of foreign land create equitable duties which will be recognized and enforced in other states, including the states in which the land is situated.

The two cases that must be considered at this point are Bullock $v$. Bullock and Fall v. Fall (Fall v. Eastin). The facts in Bullock v. Bullock ${ }^{44}$ were the following: In a proceeding for divorce in New York, the court having jurisdiction over the parties, A obtained a decree granting her a divorce from her husband and alimony of \$100 a month. The decree further directed that B secure the payment of alimony by a mortgage on New Jersey lands. $B$ failed to execute the mortgage and made various mortgages and conveyances of the lands in question without consideration for the purpose of defeating A's rights under the decree. A brought a suit in New Jersey, claiming an equitable lien on the New Jersey lands by virtue of the New York decree and praying that the mortgages and conveyances be set aside and that $B$ execute a mortgage in accordance with the New York decree. On B's motion the suit was dismissed.

Magie, J., delivering the opinion of the court, said:45

"But it is ingeniously contended in this court that the decree and order of the supreme court of New York imposed upon respondent a personal obligation to do what that decree and order had directed him to do, and that a court of equity in New Jersey ought to compel him to perform that obligation, as it would compel him to perform his contract to convey or mortgage lands in its jurisdiction. Moreover, it is contended that the provisions of section I of article 4 of the constitution of the United States, requiring full faith and credit to be given in each state to the records and judicial proceedings of every other state, impart to this decree and order a conclusive force with respect to the mortgage directed to be given on lands here, which compels our courts to enforce it by decrees in conformity therewith.

\footnotetext{
${ }^{4}$ For a discussion of these cases see Barbour, op. cit. supra * note; Goodrich, Enforcement of a Foreign Equitable Decree (I920) 5 Iowa L. BuL. 230; Notes (Ig08) 2r HARv. L. REv. 210, 354; Notes (IgI2) 25 ibid. 653; Note and CoMs- MENT (Igig) I8 Mxch. L ReV. I42; CoMments (Igif) 260 Yale LAW JOURNAI, 3II.

"Loc. cit. supra note 37 .

${ }^{\star}$ At p. 566-567, 569, 30 At1. 678 .
} 
"Doubtless the judgment of the New York court must be accorded in our courts a conclusive effect in certain respects. Thus it has conclusively determined the status of the parties to that action, and that the marital relation previously existing between them has been absolutely dissolved. If, by the direction to pay alimony, an indebtedness arises from time to time as such payments become due, an action at law would lie thereon and the decree would furnish conclusive evidence of such indebtedness.

"But the question, upon the solution of which this case must turn, is whether the courts of New Jersey must give conclusive effect to the decree or judgment of the courts of New York made in a case where they had acquired jurisdiction of the parties but affecting lands situated here, and disposing of the title thereto in whole or in part. If this question is to be answered in the affirmative, it seems evident that we accord jurisdiction over lands in New Jersey to the courts of other states, and, as was said by Chancellor Zabriskie in Davis v. Headley, supra, 'leave to the courts of this state only the ministerial duty of executing their decrees.' For the doctrine that jurisdiction respecting lands in a foreign state is not in rem but only in personam is bereft of all practical force if the decree in personam is conclusive and must be enforced by the courts of the situs. $* * *$

"The contention that such an order requiring lands in New Jersey to be charged with alimony created a personal obligation on respondent is, in my judgment, without force. It is a misuse of terms to call the burden thereby imposed on respondent a personal obligation. At the most, the decree and order imposed a duty on him, which duty he owed to the court making them. That court can enforce the duty by its process, but our courts cannot be required to issue such process or to make our decrees operate as process."

Garrison, J., wrote a concurring opinion in which he took the position that the order to execute a mortgage on New Jersey land was not a part of the New York judgment upon the issue before the court but was a mere decretal order ancillary to execution.

Van Syckel, J., dissented, on the ground that the New York decree, although it did not of its own force create a lien upon the New Jersey lands, was conclusive of A's rights to have $B$ execute a mortgage upon the New Jersey lands.

Five judges concurred with Magie and five with Van Syckel.

It should be noted that the judges in Bullock v. Bullock stood six to six on the issue before us and that Garrison, J., who cast the deciding vote, took a position which was not shared by any other judge.

The facts in Fall $v$. Fall ${ }^{46}$ were the following: Mrs. Fall got a decree of divorce from her husband in the state of Washington, the court having jurisdiction of the defendant. The court decreed also that certain property in Nebraska be set aside as her separate property and that Fall convey such property to her. In default of performance by Fall, a commissioner of the court executed under the direction of the court a deed to such land to Mrs. Fall, who obtained possession of the land. Fall, having executed a mortgage and deed of the premises subsequent

${ }^{4}$ Loc. cit. supra note 38 .

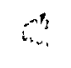


to the above decree to X, Mrs. Fall brought an action in Nebraska, setting up the Washington decree and the deed to her and prayed that the mortgage and deed by Fall to $\mathrm{X}$ be cancelled as casting a cloud on her title and that the title be quieted in her. Whether or not $X$ had notice of the Washington decree does not clearly appear. The opinion in the case before the Supreme Court of the United States seems to proceed on the assumption that $\mathrm{X}$ had notice.

Relief was granted to Mrs. Fall, which was affirmed on appeal. On a rehearing, however, it was reversed. The court distinguished Burnley $v$. Stevenson on the ground that in the case before it title had been conveyed to a third party. In this connection, the court said : $\mathbf{4}^{47}$

"But we have yet been unable to find a single case in which the direct question at issue was whether or not a decree affecting the title to real estate lying in another state will be recognized in the state in which the land lies, where no conveyance has been made in obedience to the decree, and where the title has been conveyed to third parties."

It discussed also Bullock v. Bullock, with reference to which it made the following remarks: ${ }^{4}$

"It will be seen, therefore, that neither the opinion of the majority or of the minority of the New Jersey court in Bullock $v$. Bullock would warrant the granting of the relief sought in this case, since the appellee is asking the court to give effect to a decree of the Washington court which it would not enforce if it had been rendered in a court of this state. $* * *$

"Under the laws of this state the courts have no power or jurisdiction in a divorce proceeding, except as derived from the statute providing for such actions, and in such an action have no power or jurisdiction to divide or apportion the real estate of the parties. $* * *$

"We are not compelled (under the full faith and credit clause) to recognize a decree affecting the title of $\mathrm{E}$. W. Fall and his grantees in an action where he is not in court by personal service, and where the act directed by the Washington court is in opposition to the public policy of this state in relation to the enforcement of the duty of marital support."

Upon writ of error to the Supreme Court of the United States the judgment in Fall $v$. Fall was.affirmed.99 Justices Harlan and Brewer dissented. Mr. Justice Holmes concurred specially. The majority .opinion, written by Mr. Justice McKenna, is very unsatisfactory. This is perhaps accounted for by the fact that the court received no aid from counsel, the brief submitted on behalf of Mrs. Fall being very poor indeed. No brief was filed for the defendant in error.

In the majority opinion the court dwells at length upon the inability of decrees in equity to convey legal title, a fact admitted on all sides, suggesting thereby'that an in rem effect was claimed for the Washing-

${ }^{47}$ At p. 128, I13 N. W. 178 .

${ }^{4}$ At p. 132, I33, I34, Ir3 N. W. I80, I8I.

- Fall v. Eastirn, loc. cit. supra note 39. 
ton decree. Calling attention to the fact that judgments at law can be enforced in another state only by a new suit, the court said: $:^{50}$

"Plaintiff seems to contend for a greater efficacy for a decree in equity affecting real property than is given to a judgment at law for the recovery of money simply."

The real issue, as has been stated, is whether or not the decree of equity shall be regarded as having created an equitable obligation which may be enforced elsewhere by a new suit, similarly to a foreign judgment.

Although Burnley $v$. Stevenson was deemed by the court to be opposed to the weight of authority relating to foreign equitable decrees, the opinion states that there was much temptation in the facts of this case to follow the ruling of the Ohio court. The court felt constrained, however, to affirm the Nebraska decree because of the ruling of the latter court "that the decree in Washington gave no such equities as could be recognized in Nebraska as justifying an action to quiet title." Such a ruling, it concluded, did not offend the constitution of the United States. The concurring opinion of Mr. Justice Holmes will be noticed later.

Bullock v. Bullock, Fall v. Fall, and Fall v. Eastin are the principal cases relied upon in support of the proposition that a decree for the doing of something other than the payment of money does not create a right-duty relation, an obligation, which can be enforced in another state. Attention has been called already to the fact that in Bullock $v$. Bullock only six judges supported this view, whereas six favored the enforcement of the New York decree. The decision resulted from the vote of Garrison, J., who held that the order to execute a mortgage was not a part of the decree proper but was ancillary to execution..$^{51}$ Not- . withstanding this, the case is relied upon principally by those favoring the orthodox view as supporting their position. ${ }^{52}$

The opinion in Fall v. Fall accepted neither the views of Magie, J., in Bullock v. Bullock nor those of Van Syckel, J., and rested its conclusion mainly upon the ground that the recognition and enforcement of the Washington decree would violate the policy of the state. The Supreme Court of the Uinited States also failed to take a definite stand with reference to the issue here considered.

Notwithstanding the great weight of authority in favor of the proposition that equitable decrees for the doing of something other than the payment of money create equitable obligations which can be enforced by the courts of other states, the orthodox view continues to be advocated by a certain group of writers. In a leading law review, the following statement appeared in I9I2: ${ }^{53}$

${ }^{50}$ At p. 12, 30 Sup. Ct. 8.

${ }^{51}$ It is. also noteworthy that a foreign decree has been enforced in New Jersey where it did not relate to New Jersey land. Bennett $v$. Piatt (Igr5) $85 \mathrm{~N}$. J. Eq. 436, 96 Atl. 482. "To the same effect see Fromhols v. McGahey, supra note I8.

See 3 Beale, loc. cit. supra note 7.

* Notes (IgI2) 25 HaRv. L. Rev. 653, 654. 
"Thus a decree to execute a mortgage in a foreign jurisdiction will not be enforced at the situs of the land. The rule that jurisdiction respecting foreign land is only in personam, is bereft of all practical force if the decree must be enforced by the court of the situs. Such a decree would really accord jurisdiction over its lands to a foreign court. The most serious objection is that there is no form of procedure for enforcing the personal decree of a court of equity except by order of the court rendering it. The decree is in its nature not the establishment of an obligation, but a method of enforcing an obligation-a mere form of execution."

- One of our most eminent authors, writing in I920, says: $:^{54}$

"If we are to allow a court of equity in New York to create duties to convey New Jersey land, to-day when a duty to convey land, specifically enforceable in equity, in effect, and very generally in theory involves an equitable ownership capable of assertion against the whole world, unless and until cut off by conveyance to a purchaser for value without notice, the result is to allow one state through its courts to create real rights in land in another state-and if it may do so by its courts, why not through its legislature?"

In the extract first given we meet again the notion that a decree imposing upon the defendant the duty to execute a mortgage on land in another state is not, in its nature, the establishment of an obligation, but a method of enforcing an obligation, a mere form of execution. In the light of what has been stated, it must be apparent that the duty imposed to execute a mortgage creates an equitable right in plaintiff's favor. The objection that we have no form of procedure to enforce the personal decree of a court of equity, except by order of the court rendering it, is of course no argument at all. It is true, of course, that Anglo-American law never does enforce foreign judgments or decrees as such. Process will not issue upon them in another jurisdiction. A new suit must be brought in every instance. All that is asked in the case before us is, however, that just as an action at law lies to enforce a legal obligation created by a foreign judgment, so a bill in equity or some equivalent mode of procedure shall be recognized as available to enforce an equitable obligation created by a foreign decree in equity. As equitable decrees create in modern law equitable rights there is no inherent reason why they should not be enforced elsewhere.

The real basis for the objection to the enforcement of foreign equitable decrees for the doing of something other than the payment of money arises from the feeling that such a recognition is equivalent to. allowing the courts of another state to create property rights in domestic land. Because of this, the old dogma is persisted in that equitable decrees in the absence of statute do not create obligations at all, but are only in the nature of process or execution. We have seen, however, that the great weight of modern authority is to the contrary and that the whole history of the relation between equitable decrees and

\footnotetext{
${ }^{34}$ Pound, op. cit. supra note 8, 424-425.
} 
judgments at law unmistakably points to the conclusion that they differ to-day, not as regards their essential nature and effect, but only as regards the remedy by which the legal and equitable obligations are respectively enforced.

What is there to the contention that the recognition of a foreign equitable decree for the conveyance of land or for the giving of a mortgage would be tantamount to a surrender to a foreign court of the power to control title to local real property?

In Taylor v. Taylor, decided by the Supreme Court of California in I923, it is said : 55

"That the courts of one state cannot make a decree that will operate to change or directly affect the title to real property beyond the territorial limits of its jurisdiction, must be conceded ... jurisdiction to affect the title to real property by a judgment. in rem, or directly against the thing itself, exists only in the courts of the state where the land is situated."

Such and similar statements are found in numerous decisions and are said to represent fundamental principles in our law. That being so, would the doctrine that jurisdiction with respect to land in another state is not in rem but only in personam be deprived of all practical force if the decree in personam is conclusive and must be enforced by the courts of the situs? What do the above statements actually mean? Let us see what happens if a defendant in the equitable suit, coerced by the order of the court, executes the conveyance or mortgage. Why, it is binding in our law at the situs and cannot be set aside on the ground of duress. ${ }^{56}$ But for the power or jurisdiction of the court of equity to affect the title to the foreign land, the conveyance would be annulled. No greater effect is given to the decree when it is recognized by the courts of the situs as a conclusive determination of the defendant's duty to convey. So far as the defendant is concerned, the effect is identical; namely, he is deprived of his land, and as regards the control of the situs over domestic land, it is also identical in substance. Where the defendant makes the conveyance under the compulsion of the foreign court, plaintiff's legal title to the land is established by the deed executed in conformity with the law of the situs. Where the foreign decree is made the basis of a new suit at the situs, the legal title to the lanid is established by the new decree. The difference is one of form or procedure, not one of substance.

As long as the power of foreign courts of equity exists in our law to coerce defendants to do their bidding with respect to foreign land, logic requires, unless there are reasons of policy to the contrary, that the duties imposed on the defendant be recognized and enforced at the

${ }^{85}$ (I923) I92 Calif. 7I, 76, 2I8 Pac. 756, 758.

${ }^{50}$ Gilliland v. Inabnit (I894) 92 Iowa, 46, $60 \mathrm{~N}$. W. $2 \mathrm{rI}$; Groom v. Mortimer Land Co. (1912, C. C. A. 5th) I92 Fed. 849; Putnam \& Norman v. Conner (IgI8) I44 Ia. 23r, 80 So. 265. 
situs if the defendant has succeeded in extricating himself from the clutches of the foreign court by moving to the state where the property lies before being coerced to execute the deed or mortgage. The general policy that litigation should cease and that the same issues should not be tried again between the same parties applies here with as much force as elsewhere.

Some one may ask: May it not happen that the foreign court of equity would determine the duty of the defendant to make the conveyance in accordance with some other law than that of the situs and that the courts of the situs would be bound, therefore, to enforce such duty, although no such duty would have existed under the local law of the situs? Yes, this may happen, but this is true also when the defendant is coerced by a court of equity to execute the conveyance. Where such a conveyance is made the courts of the situs do not look behind the foreign decree, to see whether the duty to convey was "created" with reference to some other law than that of the situs. The same would be true, of course, if the foreign decree is recognized as furnishing the basis for a new suit at the situs. The policy on which the doctrine of res judicata rests precludes an inquiry into the merits of the issues determined by the court.

The fundamental rule in Anglo-American law that the title to land is controlled by the law of the situs, however true it may be in general, does not mean, therefore, that all personal obligations with reference to foreign land, even if they are specifically enforceable, must be determined in accordance with the law of the situs. This appears also from a decision of Mr. Justice Holmes in Polson v. Stereart, ${ }^{57}$ in which the following were the facts: $A$ and $B$ entered into an agreement in the state of $X$, with respect to real property in the state of $Y$. The contract was valid under the law of state $X$ but would have been void if entered into in state $Y$. Suit for the specific performance of the contract was brought in state $Y$. The decision in the case was that inasmuch as what the contract called for could be done consistently with the law of the situs, specific performance should be granted. In this case, therefore, a court of the situs enforced specifically a personal duty with respect to domestic land, although such a duty could not have been created if the agreement had been made in the state where the land was.

Unless we are ready, therefore, to abandon the doctrine of this case, as well as the established doctrine that conveyances executed under the coercion of a foreign court of equity, are valid and unimpeachable in the state where the land is situated, it would seem but good sense to give the same effect to a foreign decree of equity where the defendant has escaped before complying with the decree. This is not giving an in rem effect to the equitable decree. By specifically enforcing the duty created by the foreign decree, the legal title is affected only indirectly. The title will not be changed except as the result of a decree of the court

${ }^{87}$ (1897) I67 Mass. 21r, 45 N. E. 737. 
of the situs, that is, only after there is record evidence of such change at the situs and this is the only real interest that the state of the situs has in the matter. As has been stated above, its control over the title to domestic land is no greater and no less whether the change of legal title results from the recognition of.the obligation created by the foreign decree, which is specifically enforced by the courts of the situs, or from a deed executed by the defendant in the foreign suit under coercion, or from the recognition of a personal duty to convey created by a contract in another state, which is specifically enforced by the courts of the situs, although such obligation would not have resulted from the contract if it had been entered into in the state where the land is.

If a foreign contract or a foreign decree should go beyond what was ordered in the cases that have been discussed in this paper, that is, if they should impose upon the defendant not merely a duty to convey land in accordance with the law of the situs, but the duty to execute a deed not satisfying the law of the situs as regards form or substance, the deed would be inoperative to pass the title to the land. Each state has the power to determine the conditions upon which title to land shall be held, and the mode by which legal title shall be conveyed, ${ }^{58}$ and it is not bound to recognize a foreign decree or deed executed in compliance with such a decree if it violates its policy in these respects.

Here it may be asked: Was the Supreme Court of Nebraska not justified then in declining to give effect to the Washington decree on grounds of policy? 'The policy referred to in this question is not the kind of policy just discussed. If the deed ordered to be executed by the Washington decree had been made, there would have been nothing in the law of Nebraska to prevent its recognition. . No rule of property of the state would have been violated. The policy involved in the question has, therefore, nothing to do with the power of the state to determine the title to Nebraska land, but related to the power of the Nebraska court to determine the property rights of the parties in divorce proceedings. As the Nebraska court, according to the view taken by the majority, had no power under the local legislation to impose a duty upon Mr. Fall to make a conveyance of land to Mrs. Fall when granting her a divorce, it was of course within its power to say that the recognition of the Washington decree was inconsistent with the policy of the state, provided the personal obligation created by the Washington decree was not entitled to recognition in Nebraska under the full faith and credit clause. If it did fall within the constitutional provision referred to, the defense of public policy would not avail under the decision of the Supreme Court of the United States in Fauntleroy v. Lum.59

This brings us to the final question: Is the equitable duty to convey foreign land created by a court of equity within the full faith and credit

\footnotetext{
${ }^{*}$ United States $v$. Crosby (I812) 7 Cranch, II5, 3 L. Ed. 287.
}

${ }^{\circ}$ (Ig08) 210 U. S. 230, 28 Sup. Ct. 64I. 
clause of the constitution of the United States? Let us see what Mr. Justice Holmes has to say on this subject in his concurring opinion in Fall v. Eastin: ${ }^{60}$

"The real question concerns the effect of the Washington decree. As between the parties to it that decree established in Washington a personal obligation of the husband to convey to his former wife. A personal obligation goes with the person. If the husband had made a contract, valid by the law of Washington, to do the same thing, I think there is no doubt that the contract would have been binding in Nebraska. ... So I conceive that a Washington decree for the specific performance of such a contract would be entitled to full faith and credit as between the parties in Nebraska. But it does not matter to its constitutional effect what the ground of the decree may be, whether a contract or something else. Fauntleroy v. Lum, 210 U. S. 230. (In this case it may have been that the wife contributed equally to the accumulation of the property, and so had an equitable claim.) A personal decree is equally within the jurisdiction of a court having the person within its power, whatever its ground and whatever it orders the defendant to do. Therefore I think that this decree was entitled to full faith and credit in Nebraska.

"But the Nebraska court carefully avoids saying that the decree would not be binding between the original parties, had the husband been before the court. The ground on which it goes is that to allow the judgment to affect the conscience of purchasers would be giving it an effect in rem. It treats the case as standing on the same footing as that of an innocent purchaser. Now if the court saw fit to deny the effect of a judgment upon privies in title, or if it considered the defendant an innocent purchaser, I do not see what we have to do with its decision, however wrong. I do not see why it is not within the power of the state to do away with equity or with the equitable doctrine as to purchasers with notice if it sees fit. Still less do I see how a mistake as to notice could give us jurisdiction. If the judgment binds the defendant, it is not by its own operation, even with the Constitution behind it, but by the obligation imposed by equity upon a purchaser with notrce. The ground of decision below was that there was no such obligation. The decision, even if wrong, did not deny to the Washington decree its full effect."

It is submitted that Mr. Justice Holmes has.given us the key to the final solution of our problem, which will reconcile the interests of society in enforcing rights that have been decided after a fair hearing upon the merits and not allowing them to be relitigated and the interests of a state to control the title to domestic land. And this solution is briefly the following: the foreign decree is entitled to be enforced under the full faith and credit clause as between the immediate parties, but that the state in which the property is situated may decline to give effect to it as to third parties, including purchasers with notice of the foreign decree. It must be remembered, however, that the question is ultimately whether, in view of the mischief that the full faith and credit clause was designed to prevent, equitable decrees for the conveyance of

${ }^{\infty}$ Op. cit. supra note 39 , at pp. I4-I5, 30 Sup. Ct. 9. 
foreign land should be regarded as within the purview of the constitutional provision.

The courts of the situs may of course give effect to the foreign decree, even as to third parties with notice thereof, and such effect has actually been given to them in the later cases. (Mallette v. Scheerer, Matson v. Matson, Redwood Investment Co. v. Exley, supra.)

The conclusion reached in this paper may be summarized as follows:

(I) Equitable decrees for doing something other than the payment of money create equitable rights. They do not impose merely a personal duty on the defendant with respect to the particular court, nor are they mere methods of enforcing an obligation, a form of execution.

(2) The equitable rights created by foreign decrees should, as between the parties, be recognized and enforced elsewhere, including the state in which the land lies, similarly to foreign judgments at law. That is: (a) The foreign decree may be pleaded as res judicata. (b) When the decree is in plaintiff's favor, the cause of action is merged, so that plaintiff cannot fall back on the original cause of action. (c) The obligation created by the decree may be enforced elsewhere by a new suit or may be set up, where the local law allows it, as an equitable defense.

(3) Under the full faith and credit clause, the obligation imposed by a foreign decree is, as between the parties, binding upon the courts of sister states. It is not binding, however, under the federal constitution upon third parties including parties with notice of the foreign decree. Whether foreign equitable decrees will be.recognized by the courts of the situs as to such third parties will depend upon the policy of the particular state.

It is submitted that the foregoing conclusions are more in harmony with the historical development of equity than would have been the recognition of a fundamental difference between judgments at law and equitable decrees in our law to-day. The question how far the similarity should be carried depends, of course, upon considerations of social order. From a legalistic viewpoint, it would have been perfectly proper to draw a distinction between equitable decrees for the payment of money and equitable decrees for the doing of some other act. It is obvious, on the other hand, that there is no inherent difference in the nature of the two kinds of decrees. If a distinction were to be drawn between them, it must be because of a difference in the underlying social considerations. Now, it may be argued that the social need was satisfied when equitable decrees for the payment of money were placed on the same footing as judgments at law, and most of the supporters of the orthodox view take this position. The ultimate question to be decided is, therefore, whether considerations similar to those which prompted the forward step as regards equitable decrees for the payment of money do not demand the same recognition for foreign equitable decrees for the conveyance of land? Two courses are open. 
Policy may suggest that all litigation affecting land should take place in the tribunals of the state in which the land is situated. Such a rule no doubt would give the greatest guarantee that all rights in such land would be determined in accordance with the law of the situs. In many cases, however, it would impose on one or both of the parties the inconvenience and expense of conducting litigation away from home. For this and other reasons, Anglo-American law has conferred upon courts of equity jurisdiction with respect to foreign land, provided personal service is had over the defendant. As long as this policy stands, the writer is satisfied that the recognition and enforcement of foreign equitable decrees for the conveyance of land is a desirable end. As between the courts of this country, as much effect should be given to judgments or decrees of a sister state, apart from the requirements of the full faith and credit clause, as is consistent with the interests of the forum. In view of the fact, therefore, that a conveyance of domestic land, made under the compulsion of a decree of a court of equity of another state, will be recognized, it seems but logical and just that the same recognition should be given to the decree where the defendant left the state without complying therewith. Defendant has had his day in court and there is no reason why he should be allowed to litigate the matter over again simply because he was successful in evading the duty imposed upon him in the original suit. 